\title{
HTLV-I ASSOCIATED UVEITIS, MYELOPATHY, RHEUMATOID ARTHRITIS AND SJÖGREN'S SYNDROME
}

\author{
SONIA REGINA A.A. PINHEIRO*, MARCO AURÉLIO LANA-PEIXOTO* *, ANNA B. CARNEIRO

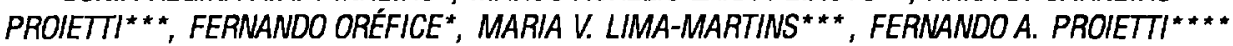

SUMMARY - A 62 year-old white female presented with a 10-year-history of slowly progressive spastic paraparesis, pain and dysesthesia in the lower limbs and sphincter disturbance. A few years after the onset of the neurologic symptoms she developped migratory arthritis with swelling of the knees and pain on palpation of knees and fingers, dry eyes, mouth and skin. Two months before admission she presented bilateral nongranulomatous anterior uveitis. Examination revealed spastic paraparesis with bilateral Babinski sign, a decreased sensation level below L3, decreased vibration sense in the lower extremities, and a postural tremor of the upper limbs. Laboratory work-up disclosed HTLV-I positive tests in the blood and cerebrospinal fluid (CSF), and a mild pleocytosis in the CSF with a normal protein content. Nerve conduction velocity studies were normal. The present case shows the association of uveitis, arthritis and Sjögren's syndrome in a patient with tropical spastic paraparesis / human T-cell lymphotropic virus type I (HTLV-I) associated myelopathy (TSP/HAM), and illustrates the wide spectrum of clinical manifestations which may accompany this infection with this virus.

KEY WORDS: HTLV-I/II, uveitis, myelopathy, spastic paraparesis, Sjögren's syndrome.

Uveite, mielopatia, artrite reumatóide e síndrome de Sjögren associadas ao HTLV-I

RESUMO: Uma mulher branca de 62 anos foi internada apresentando história de paraparesia Ientamente progressiva durante 10 anos. Dois meses antes da intemação ela apresentou uveíte anterior não granulomatosa bilateral. Poucos anos após o início dos sintomas neurológicos, ela desenvolveu artrite migratória com edema dos joelhos e dor à palpação dos joelhos e dedos dos pés, boca, pele e olhos secos. Ao exame físico foi observado paraparesia espástica com sinal de Babinski positivo, sensibilidade diminuída abaixo de L3, diminuição da sensação de vibração nas extremidades inferiores, $\mathrm{e}$ tremor postural dos membros supcriores. Apresentou testes positivos para o HTLV-I no sangue. O estudo do líquido cefalorraquidiano mostrou discreta pleocitose, proteínas normais e ELISA e Western blot positivos para o HTLV-I. O estudo da velocidade de condução dos nervos foi normal. Este caso mostra a associação de uveíte, artrite e síndrome de Sjögren em uma paciente com paraparesia espástica tropical (HTLV-I) associada a mielopatia (TSP/HAM), e ilustra o largo espectro das manifestações clínicas que podem acompanhar a infecçāo por este vírus.

PALAVRAS-CHAVE: HTLV-I/II, uveite, mielopatia, paraparesia espástica, síndrome de Sjögren.

Human T-lymphotropic virus type I (HTLV-I), a retrovirus causing adult T-cell leukemia (ATL) and lymphoma, has been also considered as an etiologic agent of a form of a chronic progressive myelopathy (TSP / HAM) occurring most commonly in some tropical countries and Japan ${ }^{16,20,22,23}$. It has been also found in association with acute granulomatous or nongranulomatous uveitis, then

Departments of Ophthalmology*, Neurology** and Preventive and Social Medicine**** , Federal University of Minas Gerais Medical School and State Center of Hematology and Hemotherapy (Fundaçāo Hemominas)*** , Belo Horizonte, MG, Brazil. Aceite: 27-junho-1995. 
called HTLV-I associated uveitis (HAU), ${ }^{10,13}$ and some systemic conditions such as thyroid dysfunction ", T-lymphocyte alveolar pneumonitis ${ }^{26}$, rheumatic and skin abnormalities ${ }^{17}$, Behçet's disease and Sjögren's syndrome ${ }^{4}$. It is most probable that immunologic factors play an important role in defining the apparent manifestation of the infection in a particular patient.

Herein we describe a patient with chronic spastic paraparesis, anterior uveitis, rheumatoid arthritis, Sjögren's syndrome and positive HTLV-I tests in the serum and the cerebrospinal fluid (CSF). This case provides evidence of the wide spectrum of clinical manifestations caused by this retrovirus. To the best of our knowledge the association of such many abnormalities in a single patient has not been reported in the literature before.

\section{CASE REPORT}

C.S., a 62-year-old white female was admitted to the hospital with a 10-year-history of pain and dysesthesia in both lower limbs followed by progressive paraparesis and sphincter disturbance which developed five years later. Three years before admission she had a rheumatologic evaluation because of swelling and pain in the wrists, knees and feet which resulted in a presumptive diagnosis of rheumatoid arthritis. She also complained of long lasting dry eyes, mouth and skin requiring perrnanent use of artificial tears and moisturizing skin lotions. Just before admission the patient developed pain and blurred vision in the right eye. On ophthalmic examination her corrected visual acuity was 0.3 in both eyes. The intraocular pressure was $9 \mathrm{mmHg}$ OD and $10 \mathrm{mmHg}$ OS. The eye positions were orthophoric and the pupils reacted fully to light. Slit-lamp examination revealed nongranulomatous uveitis bilaterally, showing $2+$ flare and cells in the anterior chamber, fine and white keratic precipitates, and $2+$ cells were found in vitreous body OD. There were $1+$ flare and cells in the anterior chamber, and a few cells in the vitreous body OS. The cornea was clear. No nodules were found in the iris or the trabecular meshwork. The superficial conjunctiva and comea stained with a $1 \%$ bengal rose solution. Schirmer test revealed impaired lacrimal secretion. Ophthalmoscopy disclosed bilateral senile macular degeneration. No oral aphthae or genital ulcers were noted. A four-week-therapy with topical corticosteroid caused diminuition of the ocular inflamatory signs.

At admission the physical examination showed a cooperative lady with normal mental state. She presented dry skin and mucosa. Examination of cranial nerves was unrevealing. There was a spastic paraparesis with increased deep tendon reflexes and the presence of Babinski sign bilaterally. Light touch and pinprick sensations were decreased below L3 level. Vibration and position sense were diminished in the lower limbs. The gait was spastic and mildly ataxic. Laboratory studies revealed normal WBC and RBC count, blood electrolytes and chemistry. Serum electrophoresis, ANA, lupus erythematosus cell preparation, VDRL and FTA-ABS, indirect immunofluorescence for toxoplasmosis and thyroid function tests were all negative. Rhe umatoid factor was positive at 1:64. HIV serology was negative but HTLV-I serology was positive by both ELISA (Ortho) and Western blot (Cambridge Biotech). Tuberculin test elicited a $10 \mathrm{~mm}$ reaction but the chest X-ray was normal. Nerve conduction studies were in the normal range. Lumbar puncture was remarkable for the presence of 24 WBC (lymphocytes and monocytes), glucose of $85 \mathrm{mg} / \mathrm{dL}$ and total protein of $24 \mathrm{mg} / \mathrm{dL}$. CSF tests for cysticercosis and syphilis were negative. ELISA and Westem blot for HTLV-I was positive in the CSF. A myelogram and a lumbar spine myelo-CTScan were normal.

\section{DISCUSSION}

The association of a chronic progressive myelopathy to human $\mathrm{T}$-cell lymphotropic virus type I (HTLV-I) was first reported by Gessain et al. ${ }^{3}$ in Martinique. Later there have been many reports of this condition from many geographical areas such as Japan, the Seychelles Islands, Caribbean basin, South America, Africa and some regions of the United States ${ }^{22,24}$. This condition has been originally referred to as HTLV-I associated myelopathy (HAM) in Japan and tropical spastic paraparesis (TSP) in the Caribbean. However as the clinical picture is similar in all endemic areas the designation HAM/TSP has had wide international acceptance. In some regions of Brazil antiHTLV-I antibodies are found in a prevalence as high as $1.8 \%$ among the general population and $22.7 \%$ among AIDS patients ${ }^{y}$. Over 400 suggestive cases of HAM/TSP have been reported in Brazil although only $32.7 \%$ of them were found to be seropositive\%. As observed in other endemic countries women and blacks were predominantly affected in Brazilian series ${ }^{2,9}$. 
The mean age of patients with TSP/HAM at onset of the disease was 42 years in the tropics and 53 years in Japan ${ }^{23}$. Occurrence of the disease in children and after 60 years old is very rare ${ }^{23}$. HTLV-I is usually transmitted by sexual contact, blood transfusion, sharing needles and breastfeeding. There is some evidence that in Northeast Brazil the virus is most commonly transmitted through heterosexual contact and in a vertical way from mother to child, mainly by breast feeding ${ }^{6}$.

Only about one of 1000 infected patients develops TSP/HAM, and the coincidence of both lymphoma or leukemia and TSP/HAM is very rare. HTLV-I primarily infects CD4+ T cells in the blood and cerebrospinal fluid but the preference to infect some specific cells in the central nervous system (CNS) has not been determined as yet. It has been well known that microglia and macrophages as well as neurons, astrocytes and oligodendrocytes are also involved, but the exact pathogenesis of CNS infection remains to be determined. Some of the pathologic changes seen in HTLV-I infection, especially lymphocytic infiltration of leptomeninges, parenchyma and perivascular spaces, suggest that immunopathogenic mechanisms may play an important role in causing neurologic damage. These infiltrates are made up of $C D 8+T$ cells ${ }^{28}$. Humoral mechanisms may also be important in the immunopathogenesis of TSP/HAM as the presence of IgM antibody and high titers of IgA and IgG antibodies to some viral proteins distinguish TSP/HAM patients from asymptomatic carriers ${ }^{5}$.

The clinical picture of HAM/TSP is characterized by bilateral and symmetrical involvement of the pyramidal tracts affecting the lower limbs resulting in spastic paraparesis or frank paraplegia, increased knees reflexes and extensor plantar responses. Spasticity is usually moderate and predominates on the thigh adductors and extensors and gastrocnemius muscles. Motor weakness is more severe proximally, affecting mainly gluteus medius and iliopsoas. Low back pain is a common complaint and results from spasticity. Spastic bladder, sphincter disturbance and impotence in males are frequently reported. Slight involvement of the posterior columns and peripheral nerves may cause plantar dysesthesia, decreased Achilles tendon reflexes, and slight loss of vibration sense in distal lower extremities. Involvement of the peripheral nervous system may be seen in up to $25 \%$ of patients while fewer patients may show signs of an inflammatory myopathy.

Cranial nerve involvement is very rare, except in Jamaican series in which retrobulbar optic neuropathy occurred in $15 \%$ and deafness in $7 \%$ of cases ${ }^{18}$. Diplopia and nystagmus were also observed in $8 \%$ of Japanese patients ${ }^{16}$. Peripheral facial paralysis may occur in rare instances ${ }^{27}$. Ataxia usually results from peripheral nerve and posterior columns lesions although cerebellar tremor has been observed in up to $20 \%$ of patients ${ }^{21}$.

Cerebrospinal fluid examination in most patients with TSP/HAM shows lymphocytic pleocytosis with cell counts usually between 6 and 40 per cubic millimeter; increased protein content and gamma-globulin fraction, predominantly IgG with oligoclonal bands ${ }^{1.25}$. Positive treponemal reactions have been reported in more than $60 \%$ of patients from Jamaica ${ }^{18}$ and in lower frequency in series from the Seychelles ${ }^{19}$, Colombia ${ }^{21}$ and Martinique ${ }^{27}$. Treponemal tests in the CSF have also been positive in $26 \%$ of patients from Jamaica ${ }^{18}$ and in $19 \%$ of patients from Colombia ${ }^{21}$ but was negative in most series from Japan ${ }^{16}$ and Brazil's. In our patient VDRL and FTA-ABS were negative in both the serum and CSF.

Patients with TSP/HAM may present some ocular and systemic abnormalities such as uveitis, retinal vasculitis, retinochoroidal degenerative changes ${ }^{11,13,14}$, signs of Sjögren's syndrome and́ Behçet's disease $^{4}$, rheumathoid arthritis ${ }^{17}$, interstitial pneumonitis ${ }^{26}$ and hyperthyroidism ${ }^{11}$.

The association of HTLV-I with idiopathic uveitis in endemic areas in Japan varies from 35.4 to $44.8 \% \%^{8,14}$.The magnitude of this association is not known in Brazil. The disease may either affects middle-aged, previously healthy HTLV-I carriers or patients with myelopathy and presents acute, granulomatous or nongranulomatous, anterior uveal inflammations accompanied by vitreous reactions and retinal vasculitis. The reactive lesions are usually mild to moderate and resolve in response to corticosteroid $^{15}$. In spite of the HAU to be associated with intermediate uveitis in the most patients, 
anterior uveitis have been described in $14 \%$ of the patients ${ }^{7,8}$ and uveitis can be unilateral (57\%) or bilateral $(43 \%)^{7}$.

Nishioka and associates ${ }^{12}$ studied eleven patients with chronic arthritis who had high HTLVI antibody titres in both sera and synovial fluids. The mean age of patients in this group was 63 years, and the average age at onset was 49 years; both of these values are greater than the usually reported for rheumatoid arthritis. All eleven patients were women and the clinical picture was typically one of chronic oligoarthritis, with the shoulders, wrists, and knees being preferentially involved. Our patient had a long history of rheumatoid arthritis and a positive titer of rheumatoid factor in the serum. In addition to that she also complained of dry mouth, skin and had keratoconjunctivitis sicca suggesting the presence the Sjögren's syndrome. Association between HTLV-I infection and Sjögren's syndrome has been rarely reported ${ }^{4}$.

The present case is of particular interest in that it shows the association of HAM/TSP with HAU, rheumatoid arthritis and Sjögren's syndrome illustrating the wide spectrum of disorders caused by the HTLV-I/II. The exact pathogenetic mechanisms determining the multiple manifestations of this viral infection in a single patient remains to be elucidated.

\section{REFERENCES}

1. Bhagavati S, Ehrlich G, Kula RW, Kwok S, Sninsky J, Udani V, Poiesz BJ. Detection of T-cell lymphoma/ leukemia virus type I DNA and antigen in spinal fluid and blood of patients with chronic progresssive myelopathy. N Engl J Med 1988; 318:1141-1147.

2. DeCastro Costa CM, Carton H, Goubau P, Almeida JAC. Brazilian studies on tropical spastic paraparesis: a meta-analysis. Arq Neuropsiquiatr 1994; 52:585-591.

3. Gessain A, Vernant JC, Maurs L, Barin F, Gout O, Calender A, De Thé G. Antibodies to human Tlymphotropic virus type I in patients with tropical spastic paraparesis. Lancet 1985; 2:156-157.

4. Kanazawa H, Ijichi S, Eiraku N, Tadahiko I, Higuchi I, Nakagawa M, Kuriyama M, Tanaka S, Osame M. Behçet's disease and Sjögren syndrome in a patient with HTLV-I-associated myelopathy. J Neurol Sci 1993; 119:121-122.

5. Kira J, Nakamura M, Sawada T, Koyanagi Y, Ohori N, Itoyama Y, Yamamoto M, Sakaki Y, Goto I. Antibody titers to HTLV-I-p40 ${ }^{12 x}$ protein and gag-env hybrid protein in HTLV-I associated myelopathy/tropical spastic paraparesis: correlation with HTLV-I proviral DNA load. J Neurol Sci 1992; 107:98-104.

6. Melo A, Gomes I, Mattos K. Mielopatias por HTLV-I na cidade de Salvador, Bahia. Arq Neuropsiquiatr $1994 ; 52: 320-325$.

7. Mochizuki M, Watanabe T, Yamaguchi K, Tajima K, Yoshimura K, Nakashima S, Shirao M, Araki S, Miyata N, Mori S, Takatsuki K. Uveitis associated with human T lymphotropic virus type I: seroepidemiologic, clinical and virologic studies. J Infect Dis 1992; 166:943-944.

8. Mochizuki M, Watanabe T, Yamaguchi K, Yosshimura K, Nakashima S, Shirao M, Araki S, Takatsuki K, Mori S, Miyata N. Uveitis associated with human T-cell lymphotropic virus type I. Am J Ophthalmol 1992; 114:123-129.

9. Moreira ED Jr, Ribeiro TT, Swanson P, Sampaio C, Melo A, Brites C, Badaró R, Toedter G, Lee H, Harrington W Jr. Seroepidemiology of human T-cell lymphotropic virus type I /II in Northeastern Brazil. J AIDS 1993; 959-963.

10. Nakao K, Ohba N. Clinical features of HTLV-l associated uveitis. Br J Ophthalmol 1993; 77:374-279.

11. Nakao K, Ohba N, Otsuka S, Okubo A, Yanagita T, Hashimoto N, Arimura H. HTLV-I associated uveitis and hyperthyreoidism. Jpn J Ophthalmol 1994; 38:56-61.

12. Nishioka K, Maruyama I, Sato K, Kitajima I, Nakajima Y, Osame M. Chronic inflammatory arthropathy associated with HTLV-I . Lancet. 1989; 25:441.

13. Ohba N, Matsumoto M, Sameshima M, Kabayama Y, Nakao K, Unoki K, Uehara F, Kawano K, Maruyama I, Osame M. Ocular manifestations in patients infected with human T-lymphotropic virus type I. Jpn J Ophtalmol 1989; 33:1-12.

14. Ohba N, Nakao K Isashiki Y, Osame M, Sonoda S, Yashiki S, Yamaguchi K, Tagima K and The Study Group for HTLV-I Associated Ocular Diseases. A multicenter case-control study of HTLV-I associated uveitis. Jpn J Ophthalmol 1994; 38:162-167.

15. Ohba N, Nakao K, Iashiki Y, Kaminagayoshi T, Sonoda S, Yashiki S, Osame M, and The Study Group for HTLV-I Associated Ocular Diseases. Clinical features of HTLV-I associated uveitis determined in multicenter collaborative study. Jpn J Ophthalmol 1994; 38: 168-174. 
16. Osame M, Igata A, Matsumoto M, Usuku A, Kitajima I, Katahashi K. On the discovery of a new clinical entity: humam T-cell lymphotropic virus type I-associated myelopathy (HAM). Adv Neurol Sci 1987; 31:727-745.

17. Osame M, McArthur JC. Neurologic manifestations of infection with human T-cell lymphotropic virus type I. In Asbury AK, McKahnn GM, McDonald WI (eds). Diseases of the nervous system: clinical neurobiology. Philadelphia: Saunders, 1992; p1331-1339.

18. Rodgers PEB. The clinical features and aetiology of the neuropathic syndrome in Jamaica. West Ind Med J $1965 ; 14: 36-47$.

19. Roman GC, Spencer PS, Schoenberg BS, Hugon J, Ludolph A, Rodgers-Jonhson P, Osuntokun BO, Shamlaye CF. Tropical spastic paraparesis in the Seychelles Islands: a clinical and case-control neuroepidemiologic study. Neurology 1987; 37:1323-1328.

20. Roman GC. Retrovirus-associated myelopathies. Arch Neurol 1987; 44:659-663.

21. Roman GC, Roman LN. Tropical spastic paraparesis: a clinical study of 50 patients from Tumaco (Colombia) and review of the worldwide features of the syndrome. J Neurol Sci 1988; 87:121-138.

22. Roman GC. The neuroepidemiology of tropical spastic paraparesis. Ann Neurol 1988; 23(Suppl): 113-130.

23. Roman GC Tropical spastic paraparesis and HTLV-I myelitis. In Vinken PJ, Bruyn BW, Klawans HL(eds). Handbook of clinical neurology.Amsterdam: Elsevier, vol.56, p 525-542.

24. Sheremata WA, Berger JR, Harrington WJ Jr, Ayyar DR, Stafford M, DeFreitas E. Human T-lymphotropic virus type I-associated myelopathy. A report of ten patients born in the United States. Arch Neurol 1992; 49:1113-1118.

25. Spina-França A, Livramento JA, Machado LR, Gomes HR, Viana LS, Castro LHM, Nóbrega JPS, Bacheschi LA. HTLV-I antibodies in serum and cerebrospinal fluid in tropical spastic paraparesis in Brazil. Arq Neuropsiquiatr 1990; 48:441-447.

26. Sugimoto M, Nakashima H, Watanabe H, Uyama E, Tanaka F, Ando M, Kawasaki S. T-lymphocyte alveolitis in HTLV-I associated myelopathy. Lancet 1987; 2:1220.

27. Vernant JC, Maurs L, Gout O, Buisson G, Plumelle Y, Neisson-Vernant C, Monplaisir N, Roman GC. HTLV-I associated tropical spastic paraparesis in Martinique: a reappraisal. Ann Neurol 1988; 23(Suppl): 133 135

28. Wayne Moore GR, Traugott U, Scheinberg LC, Raine CS. Tropical spastic paraparesis: a model of virusinduced cytotoxic T-cell-mediated demyelination? Ann Neurol 1989; 26:523-530. 